Anna Rakowska-Trela

University of Łódź (Poland)

\title{
Current Amendments to Polish Electoral Law in the Light of European Standards
}

\begin{abstract}
In December 2017 and January 2018, the Sejm and Senate, thanks to the votes of the deputies of ruling party Law and Justice, passed hugely controversial law amending inter alia Polish Electoral Code. Its adoption was opposed by the parliamentary opposition, by the electoral administration bodies and by many experts, however unsuccessfully. The enactment of this law destabilises the electoral system without a clear or evident need and treats the electoral code as a political instrument. Secondly, it does not provide the sufficient time for adaptation (vacatio legis), which may jeopardise free and fair local elections and the stability of the political system. Thirdly, the bill contains numerous unclear provisions and is in many parts written in a careless and contradictory way. Such amendments do not correspond with the European standards, described in the Venice Commission's Code of Good Practice in Electoral Matters.
\end{abstract}

Keywords: election, electoral law, Electoral Code, amendments, Poland

Democratic electoral law is the essence of representative democracy. Modern democratic countries attach great importance to the protection of electoral standards. On November 8, 2001 the Standing Committee of the Parliamentary Assembly of the Council of Europe adopted Resolution inviting the Venice Commission ${ }^{1}$ to devise a code of practice in electoral matters. As the result, the Code of Good Practice in Electoral Matters was adopted by the Venice Commission at its $51^{\text {st }}$ and $52^{\text {nd }}$ session, on July 5-6, 2002 and October $18-19,2002^{2}$.

${ }^{1}$ See more: http://www.venice.coe.int/webforms/events/.

${ }^{2}$ Code of Good Practice in Electoral Matters.

Guidelines and Explanatory Report; http://www.venice.coe.int/webforms/documents/default. aspx?pdffile=CDL-AD(2002)023rev-e (28.02.2018.); see more: C. Fasone and G. Piccirilli, Towards a Ius Commune on Elections in Europe? The Role of the Code of Good Practice in Electoral Matters in "Harmonizing” Electoral Rights, „Election Law Journal” 2017, vol. 16, pp. 247-253. 
For this study it is important that the Code stipulates five principles underlying Europe's electoral heritage stating that elections are universal, equal, free, and there are direct suffrage and secret ballot. In the opinion of the authors of the Code, "the fundamental elements of electoral law, in particular the electoral system membership in the electoral commissions and the drawing of constituency boundaries, should not be open to amendments less than one year before an election, or should be written in the constitution or at a level higher than ordinary law". In this aspect, in the Explanatory Report it is described, that the stability of the law is crucial to credibility of the electoral process, which is itself vital for the consolidation of democracy. Rules which change frequently - and especially rules which are complicated - may confuse voters. Above all, voters may conclude, rightly or wrongly, that electoral law is simply a tool in the hands of those in power, and that their own votes have little meaning in deciding the results of elections. What's more, the stability of some of the most specific rules of electoral law, especially those covering the electoral system per $s e$, the composition of electoral commissions and the drawing of constituency boundaries are crucial. These three elements are often, rightly or wrongly, regarded as decisive factors in the election results, and care must be taken to avoid not only manipulation to the advantage of the party in power, but even the mere semblance of manipulation ${ }^{3}$.

Pursuant to the regulation of the Code, the bad thing is changing the electoral systems frequently or just before (which means along the year before) elections. Even when no manipulation is intended, the changes - in the opinion of the Venice Commission - may seem to be dictated by a particular party's political interests.

Furthermore, elections must be organised by an impartial body, which means, that independent, impartial electoral commissions must be set up at all levels, starting from the national level to polling station level. There shall be no controversies in the appointing members of the Central Electoral Commission; the ruling party should not have a dominant position in the election administration.

Turning to the situation in Poland, in December 2017 and January 2018, the Sejm and Senate passed hugely controversial law amending inter alia Polish Electoral Code (pl.kodeks wyborczy, k.w. $)^{4}$, that even might change the constitutional setup in Poland without changing a letter of the constitution itself ${ }^{5}$. Members of the Sejm voted 234 to $199^{6}$ to approve a bill put forward by the ruling Law and Justice party (pl.Prawo i Sprawiedliwość, PiS) that will make significant changes to local election laws and key electoral bodies, less than a year before regional elections. The law assumes, according to its title, to „increase the participation of

3 Point 63. and 64. of the Explanatory Report.

${ }^{4}$ Dz.U. 2011 nr 21 poz. 112.

${ }^{5}$ http://www.sejm.gov.pl/Sejm8.nsf/PrzebiegProc.xsp?id=2F3E1A7FE6AD7A70C12581D700511502, 03.02.2018.

${ }^{6}$ http://www.sejm.gov.pl/Sejm8.nsf/agent.xsp?symbol=glosowania\&nrkadencji=8\&nrposiedzenia=54\&nrglosowania $=107,03.02 .2018$. 
citizens in the process of electing, functioning and controlling certain public bodies" (doc. 2001) $)^{7}$. In large parts, it consists of amendments to the Polish Electoral Code. Its adoption was opposed by the parliamentary opposition, by the electoral administration bodies and by many experts, however unsuccessfully. The President of the Republic signed it and ordered its promulgation in the Journal of Laws of the Republic of Poland ${ }^{8}$.

It has to be noted, that the law had been voted through the lower house shortly before Poland's upper house approved a controversial judicial reform, which is also essential for electoral process (in Poland the Supreme Court adjudicates upon the validity of the elections to the Sejm, to the Senate and the President's election).

In my opinion, the enactment of this law may violate the principle of a democratic state ruled by law (Article 2 of the Constitution of the Republic of Poland) in three ways: first, it destabilises the electoral system without a clear or evident need and treats the k.w. as a political instrument. Secondly, it does not provide the sufficient time of adaptation (vacatio legis), which may jeopardise free and fair local elections and the stability of the political system. Thirdly, the bill contains numerous unclear provisions and is in many parts written in a careless and contradictory way. Some of the proposed changes are manifestly unconstitutional, some are a regression compared to the current solutions the introduction of which lowers electoral standards and weakens the transparency and fairness of the elections. Proposed amendments initially assumed':

1. Introducing the definition of " $\mathrm{x}$ " as a sign comprising at least two lines that intersect within the box (Article 4 point 2 of the bill, till now exactly two lines that intersect within the box);

2. The transfer of competence to divide the commune into permanent constituencies, to change this division and to determine their numbers, borders and where shall be situated scrutiny commissions for the district electoral commissioner (article 4 point 5 of the draft bill);

3. Abolishing the possibility of postal voting (Article 4 point 23 of the bill), which was highly controversial proposal for disabled persons;

4. Introduction in the place of scrutiny commissions - scrutiny commissions consisting of commission for voting and a scrutiny commission for counting votes (Article 4 point 65 of the draft);

5. Regulating the method of counting votes in such a way that after removing the ballot papers from the ballot box, the chairman of the scrutiny commission in the presence of at least $2 / 3$ of commission members has to take each ballot paper, show every ballot paper the others and to announce loudly whether the ballot paper is valid, whether the vote is

${ }^{7}$ http://www.sejm.gov.pl/prawo/kodeks/kodeks.htm, 02.03.2018.

8 The act amending certain acts to increase the participation of citizens in the election, operating and controlling certain public authorities; Dz. U.2018, poz. 130.

${ }^{9}$ http://www.sejm.gov.pl/Sejm8.nsf/druk.xsp?nr=2001, (28.02.2018). 
valid and which candidate is indicated. Each of the present members of the commission is to write down the statement of the chairman; at any time, he may request to check a ballot paper (Article 4 point 28 of the bill);

6. The introduction of chapter $11 \mathrm{a}$, regulating institutions of scrutineers and public observers;

7. Changing the definitions and rules of conducting electoral campaign, including new rules of financing electoral campaign (Article 4, point 45);

8. Changing the composition and appointment of the National Electoral Commission (pl.Państwowa Komisja Wyborcza, PKW), by introducing solutions according to which the National Electoral Commission shall be composed of: one judge of the Constitutional Tribunal, designated by the President of the Tribunal, one judge of the Supreme Administrative Court, designated by the President of the Supreme Administrative Court, and seven persons, indicated by the Sejm, whose the term of office in the PKW shall correspond to the term of office of the Sejm. Candidates for members of National Electoral Commission shall appoint parliamentary clubs, however, the number of these members must reflect proportionally representation in the parliament of deputies' clubs (Article 4, point $51 \mathrm{draft}$ act);

9. The introduction of the election commissioners of voivodeship and poviat election commissioners; instead of being judges, they shall only have a degree in law. (Article 4 point 59 of the bill). During the legislative process this proposition has been amended in such a way, that there shall be 100 election commissioners with no distinction, but they still do not have to be judges;

10. Giving priority to nominate candidates to electoral commissions for scrutiny committees formed by political parties or coalitions of political parties, from which lists in the last elections were elected councilors to regional assemblies or Deputies (members of the Sejm).

11. The competence to establish district electoral commissions was proposed to be handed over to election commissioner (Article 4, point 65 of the draft).

12. The introduction of regulations under which the Head of the National Electoral Office (pl.Krajowe Biuro Wyborcze, KBW) would be appointed by the PKW for a period of seven years, from among candidates nominated by the President of the Republic, Sejm, Senate, each of these organs may submit only one candidate (Article 4 point 70 of the bill). During the legislative process this proposition was amended in such a way, that the candidates shall be proposed by the Minister of Interior.

13. Introduction of regulations limiting the expenditure limits in local elections in such a way those limits contain only expenditure for advertising (in press, radio, television and other media), which can jeopardise the principle that the financing of political parties and electoral campaigns shall be open to public inspection.

14. The elimination of single-mandate constituencies and majority elections in communes which are not poviat cities - during the legislative process this amendment was not retained; 
15. Reducing of the number of councillors elected in districts in local elections to $3-7$;

16. Limiting the mayor (city president) to two terms in office. Here it should be pointed out that the draftsmen it introduced a transitional provision, which suggested, that this rule shall be in force during the local elections in 2018.

The most controversial proposals concerned the changes in electoral administration. The supreme body of electoral oversight in Poland, the National Electoral Commission is permanent and currently consists of nine judges from the Supreme Court (3), the Supreme Administrative Court (3) and the Constitutional Tribunal (3). As members of the judiciary, they are professionally used to work under the conditions of impartiality and independence, which safeguard the trust placed by the public in the correctness of the electoral process.

PKW organises all elections in Poland ${ }^{10}$. This Commission oversees the entire electoral process. It is responsible for the registration of parties and candidates, manages the voter rolls, supervises elections and announces final election results. Furthermore, PKW monitors party finances and can withhold state subsidies for parties. The PKW appoints District Electoral Commissions (pl.Okręgowe Komisje Wyborcze, OKW) in the presidential and parliamentary elections and elections to the European Parliament. In contrast to PKW, OKWs are temporary. The importance of the PKW goes well beyond the election itself and - what is also crucial for the Polish party system and democracy - also includes control over the allocation of funds to political parties, which is a huge source of income for parties.

That would dramatically change after entering the amendment into force: according to the new bill, only two of the nine members would be judges, the rest being appointed by the political factions represented in the Sejm according to their respective share of seats. That would entail a considerable politicisation of the National Electoral Commission ${ }^{11}$. It has to be noted, that this amendment will enter into force after the parliamentary election in 2019. So, under the new law, the main body in charge of elections, PKW, will be completely restructured. The Supreme Court - which protested loudly against the politicisation of

${ }^{10}$ Read more: A. Kisielewicz, Note to art. 157, in K.W. Czaplicki, B. Dauter, S. J. Jaworski, A. Kisielewicz, F. Rymarz, Kodeks wyborczy. Komentarz, Warszawa: Wolters Kluwer 2014, notes no. 1-4; F. Rymarz, Konstytucjonalizacja Państwowej Komisji Wyborczej (wnioski de lege ferenda), in F. Rymarz, Demokratyczne standardy prawa wyborczego Rzeczypospolitej Polskiej. Teoria i Praktyka, Warszawa: Państwowa Komisja Wyborcza 2005, p. 237-239, A. Kisielewicz, Ustrój i zadania organów wyborczych w Polsce, in Międzynarodowa Konferencja Naukowa pt. Prawo wyborcze i system partyjny na Litwie i w Polsce: teoria i praktyka, Vilnus: The Central Electoral Commisssion of the Republic of Lithuania 2013, p. 68-69; R. Tkacz, Organy wyborcze - funkcje, zadania oraz pozycja ustrojowa, in W. Hermeliński, B. Tokaj, 25 lat demokratycznego prawa wyborczego organów wyborczych w Polsce (1991-2016), Warszawa: Państwowa Komisja Wyborcza 2016, part 1, p. 183-184

${ }^{11}$ Read more: Analiza skutków niektórych zmian w Kodeksie Wyborczym proponowanych w projekcie, Warsaw: Fundacja Batorego 2017, p. 5. 
judiciary in 2017 - would lose its representation in the PKW. There is one more point: PiS already controls the Constitutional Tribunal, following actions taken in 2015 and 2016 and the Constitutional Tribunal will still be represented.

As to the electoral administration local level, the bill calls for the appointment of 100 new commissioners, who do not have to be judges either and who would take the place of the current 51 existing commissioners ${ }^{12}$. They would be in charge to draw new electoral maps and define constituencies after this years' election. This is a task that requires a comprehensive analysis of the sociological determinants in the respective area and should not be tackled by completely inexperienced commissioners. What is more, this should be still the competence of municipalities and local authorities, like it is currently.

It has to be noted, that the responsibility in local electoral districts will fall upon 100 commissioners, who will be appointed by PKW, but from the candidates proposed by the Minister of Interior. There is the additional provision that if none is accepted or if the PKW fails to appoint them within 100 days after the entry of the law in force, they will be appointed directly by the Minister of Interior. The commissioners will therefore be the representatives of the Minister rather than of the PKW in their districts ${ }^{13}$.

According to the new law, within 60 days of its entry in force, the local self-governments (communes) will be obligated to redraw the boundaries of the constituencies. If they will not, it will be done by the commissioners (appointed from the lists supplied by the Minister or even directly appointed by the Minister). Then the wojewoda (the head of state administration at the level of voivodeship) will have the right to change these boundaries. It has to be noted, that in the future (after the elections of 2018) the commissioners will maintain the right to change the boundaries of the constituencies.

It is also necessary to point out that the institution that provides administrative support for the PKW is the National Election Bureau (pl.Krajowe Biuro Wyborcze, or KBW). The KBW coordinates the technical, financial and organisational aspects of the election process. The candidates for the head of the National Electoral Bureau, that is another dangerous feature of the new bill, are appointed by the Minister of the Interior. Exercising this competence, in February 2018 the Minister appointed three persons: Magdalena Pietrzak, Mirosław Sanek and Paweł Szrot. All three candidates had some kind of connection with the Poland's

12 Read ore abort commissioners in Polish electoral law: B. Szcześniak, Kompetencje komisarzy wyborczych, historia rozwoju i pożądane kierunki zmian, in F. Rymarz, Demokratyczne standardy prawa wyborczego Rzeczypospolitej Polskiej. Teoria i Praktyka, Warszawa: Państwowa Komisja Wyborcza 2005, p. 337 and forward; about the role of the judges in Polish electoral administration: A. Zoll, Rola sędziów w administracji wyborczej, in W. Hermeliński, B. Tokaj, 25 lat demokratycznego prawa wyborczego organów wyborczych w Polsce (1991-2016), Warszawa: Państwowa Komisja Wyborcza 2016, part 2, p. $29-31$.

13 W. Sadurski, Who will Count the Votes in Poland?; https://verfassungsblog.de/who-will-count-the-votes-in-poland/, (28.02.2018). 
ruling party Law and Justice. The PKW chose Magdalena Pietrzak for this office ${ }^{14}$. She took up her duties on March 3,2018. Until that time she had worked in a high administrative governmental office, as a deputy director of the department of parliamentary affairs of the office of Prime Minister - a certainly well placed person in the governmental bureaucracy under PiS ${ }^{15}$.

Aside from the changes in electoral administration there are also another, very controversial changes. The new bill bans candidates from simultaneously running for a mayoralty and district council. It requires that events in polling stations are filmed and stored for two years. There is no clear justification for such a change. It will restrict passive electoral rights without the need for such a regulation.

Last but not least, the new bill limits the number of terms of office for mayor to a maximum of two, which has met with criticism from political parties and local organisations. It has to be noted, that the bill's draft proposed to abolish the possibility of postal voting (Article 4 point 23), which is highly controversial for disabled persons, but during the parliamentary works deputies did not approve this amendment. This proposal did not have any basis in the Code of Good Practice in Electoral Matters. The Polish postal service is rather safe, reliable, and it functions properly.

In addition, it should be kept in mind that in December 2017 the Polish Parliament also approved a controversial judicial reform, which is also essential for the electoral process. Now electoral disputes will be considered by a new chamber of the Supreme Court, composed exclusively of judges appointed by a "new" National Council of Judiciary (pl.Krajowa Rada Sądownictwa, KRS), with the majority of members elected by the parliamentary majority. All this shows that the electoral process will be fully controlled by the ruling party, from the beginning to the end, i.e. either by the parliamentary majority or by the Minister of Interior, who is a party activist and member of a narrow party leadership in PiS.

It has to be noted, that in December 2017 Venice Commission adopted Opinion on the Draft Act amending the Act on The National Council Of The Judiciary, on the Draft Act Amending The Act On The Supreme Court, proposed by the President of Poland, and on The Act On the Organisation of Ordinary Courts, which is very critical towards Poland. The Venice Commission stipulated, that the proposed election (now in force) of the 15 judicial members of the National Council of the Judiciary by Parliament, in conjunction with the immediate

${ }^{14}$ PKW wybrała Magdalenę Pietrzak na Szefa Krajowego Biura Wyborczego; http://pkw.gov.pl/336_ Wydarzenia/1/0/24338_PKW_wybrala_Magdalene_Pietrzak_na_Szefa_Krajowego_Biura_Wyborczego, 28.02.2018.

15 Wojciech Sadurski indicates, that: „The election of the Head of the Bureau a few days ago, on 21 February 2018, confirmed the worst fears of politicisation of that office: PKW (still in its "old", and about-to-expire iteration) elected one of the three candidates presented to it by minister of interior Mr Joachim Brudziński (the most trusted collaborator of the leader of PiS, Jarosław Kaczyński)"; Who will Count the Votes in Poland?; https://verfassungsblog.de/who-will-count-the-votes-in-poland/, (28.02.2018). 
replacement of the currently sitting members, will lead to a far reaching politicisation of this body. The creation of two new chambers within the Supreme Court (Disciplinary Chamber and Extraordinary Chamber) composed of newly appointed judges and entrusted with special powers, places these chambers above all others and is ill-advised. The early removal of a large number of the Supreme Court judges (including the First President) by applying to them, with immediate effect, a lower retirement age also violates their individual rights and jeopardises the independence of the judiciary as a whole ${ }^{16}$. It is important to remember, that the Supreme Court in Poland is involved into parliamentary and presidential electoral process, because it shall adjudicate upon the validity of these elections.

Most importantly, however, a de facto subordination of the electoral personnel to politicians of the ruling party (namely, to the Minister for Interior), resulting from the elimination of judges both in PKW and as commissioners in the electoral districts, completely erodes the process of its integrity and cooperation. Taking into account some politically sensitive functions of the PKW even outside the election process, namely the supervision of the spending of state subsidies by the political parties (with the sanctions in the form of refusing public funds to parties with regard to which financial irregularities have been found; in the extreme, the PKW can initiate the procedure for banning a party), entrusting these functions to representatives of the ruling party may be catastrophic for the freedom of political parties, political pluralism and for the democratic process in general. As the current National Council of Judiciary stated in its opinion on the draft, "with the new composition of the National Electoral Commission, large parliamentary parties will be able to hamper the day-to-day functioning of their political opponents, which may be a real threat to the functioning of democratic system in Poland"17.

This law, pushed through by Law and Justice, the anti-democratic ruling party, in my opinion will lead to politicisation of the electoral administration, so there are risks of loosing the transparency of upcoming elections. Changes in the division into constituencies in

${ }^{16}$ Opinion on the Draft Act amending the Act on The National Council Of The Judiciary, on the Draft Act Amending The Act On The Supreme Court, proposed by the President of Poland, and on The Act On the Organisation of Ordinary Courts, p. 26.

17 The National Council of Judiciary (KRS) stated in its opinion, that "with the new composition of the National Electoral Commission, large parliamentary parties will be able to hinder the day-to-day functioning of their political opponents, which may be a real threat to the functioning of democratic system in Poland" Opinia Krajowej Rady Sądownictwa z dnia 7 grudnia 2017 w przedmiocie poselskiego projektu ustawy o zmianie niektórych ustaw $w$ celu zwiększenia udziału obywateli $w$ procesie wybierania, funkcjonowania i kontrolowania niektórych organów publicznych" [Opinion of the National Council of Judiciary of 7 December 2017 concerning a private members' bill on change of certain statutes aimed at increasing the participation of citizens in the process of electing, functioning and supervision of certain public bodies], 7 December 2017; http://www.krs.pl/pl/dzialalnosc/opinie-i-stanowiska/f,190,opinie-i-stanowiska-2017-r/657,5-7-grudnia/5152,opinia-krajowej-rady-sadownictwa-z-dnia-7-grudnia-2017-r-nr-wo-020-13517-druk-sejmowy-nr-2001 (28.02.2018) 
local elections may lead to the situation, in which PiS will win, which will not correspond to the actual public opinion and the real political support for the parties. The coincident politicisation of the Polish Supreme Court and the other courts, which adjudicate upon the validity of the elections, may raise serious doubts regarding the fairness of the elections held in 2018 (and in next years) ${ }^{18}$.

Such amendments do not correspond with the European standards described in the Venice Commission's Code of Good Practice in Electoral Matters. There is a threat that the Polish electoral administration (electoral commissions and commissioners, the head of the National Electoral Bureau) will not be any longer impartial and professional. Giving the new commissioners the law to redraw the boundaries of the constituencies into permanent constituencies and - what's more important - of the constituencies - brings the risk of gerrymandering. The politicisation of electoral administration is a step backwards in the Polish electoral legislation. This change of the electoral law and the election framework shall be critical to the future of Poland and its democratic system. The new electoral law is also expected to add to Poland's conflict with its EU partners.

\section{References:}

Name, S. (Year).“Title of paper”. Title of journal, 1(1), pp. 100-111. DOI: xxx.

\section{Documents:}

Code of Good Practice in Electoral Matters was adopted by the Venice Commission at its $51^{\text {st }}$ and $52^{\text {nd }}$ session, on July 5-6, 2002 and October 18-19,2002.

The act amending certain acts to increase the participation of citizens in the election, operating and controlling certain public authorities, Dz. U. 2018, poz. 130.

Analiza skutków niektórych zmian w Kodeksie Wyborczym proponowanych w projekcie, Warsaw: Fundacja Batorego 2017.

Opinion on the Draft Act amending the Act on The National Council Of The Judiciary, on the Draft Act Amending The Act On The Supreme Court, proposed by the President of Poland, and on The Act On the Organisation of Ordinary Courts.

\section{Literature:}

Czaplicki, K.W., Dauter, B., Jaworski, S.J., Kisielewicz, A., Rymarz, F. (2014). Kodeks wyborczy. Komentarz. Warszawa: Wolters Kluwer.

18 See more: Poland's ruling party plans legal changes ahead of 2018 local elections, https://www. reuters.com/article/us-poland-politics-election/ polands-ruling-party-plans-legal-changes-ahead-of-2018local-elections-idUSKBN1DA2EX?il=0, (28.02.2018), POLAND: Electoral and Judiciary Reforms, http:// cecgr.com/2017/12/18/ poland-electoral-judiciary-reforms/, (28.02.2018), Poland's lawmakers approve controversial electoral law; http:/www.dailymail.co.uk/wires/ap/article-5259047/Polands-lawmakersapprove-controversial-electoral-law.html, (28.02.2018). 
Fasone, C. and Piccirilli, G. (2017). "Towards a Ius Commune on Elections in Europe? The Role of the Code of Good Practice in Electoral Matters in 'Harmonizing' Electoral Rights”, Election Law Journal, Vol. 16, p. 247-253.

Kisielewicz, A. (2013). “Ustrój i zadania organów wyborczych w Polsce”. In Międzynarodowa Konferencja Naukowa pt. Prawo wyborcze i system partyjny na Litwie i w Polsce: teoria i praktyka. Vilnus: The Central Electoral Commisssion of the Republic of Lithuania, p. 68-69.

Rymarz, F. (2005). “Konstytucjonalizacja Państwowej Komisji Wyborczej (wnioski de lege ferenda)”. In F. Rymarz, Demokratyczne standardy prawa wyborczego Rzeczypospolitej Polskiej. Teoria i Praktyka. Warszawa: Państwowa Komisja Wyborcza, p. 237-239.

Szcześniak, B. (2005). “Kompetencje komisarzy wyborczych, historia rozwoju i pożądane kierunki zmian”. In Rymarz F., Demokratyczne standardy prawa wyborczego Rzeczypospolitej Polskiej. Teoria i Praktyka. Warszawa: Państwowa Komisja Wyborcza, p. 337.

Tkacz, R. (2016). “Organy wyborcze - funkcje, zadania oraz pozycja ustrojowa”. In W. Hermeliński, B. Tokaj, 25 lat demokratycznego prawa wyborczego organów wyborczych w Polsce (1991-2016). Warszawa: Państwowa Komisja Wyborcza, part 1, p. 183-184.

Zoll, A. (2016). "Rola sędziów w administracji wyborczej”. In W. Hermeliński, B. Tokaj, 25 lat demokratycznego prawa wyborczego organów wyborczych w Polsce (1991-2016), Warszawa: Państwowa Komisja Wyborcza, part 2, p. 29-31.

\section{Internet sources:}

Sadurski W., Who will Count the Votes in Poland?; https://verfassungsblog.de/who-will-count-the-votesin-poland

PKW wybrała Magdalenę Pietrzak na Szefa Krajowego Biura Wyborczego; http://pkw.gov.pl/336_Wydarzenia/1/0/24338_PKW_wybrala_Magdalene_Pietrzak_na_Szefa_Krajowego_Biura_Wyborczego

Poland's ruling party plans legal changes ahead of 2018 local elections, https://www.reuters.com/article/ us-poland-politics-election/polands-ruling-party-plans-legal-changes-ahead-of-2018-local-electionsidUSKBN1DA2EX?il=0

POLAND: Electoral and Judiciary Reforms, http://cecgr.com/2017/12/18/poland-electoral-judiciaryreforms/

Poland's lawmakers approve controversial electoral law; http://www.dailymail.co.uk/wires/ap/article-5259047/Polands-lawmakers-approve-controversial-electoral-law.html 